Social Science Perspectives in Early Christian Studies in a Nordic Context. Biblical Theology Bulletin 2018 ;Volum 48.(2) s. 76-84

\title{
SOCIAL SCIENCE PERSPECTIVES IN EARLY CHRISTIAN STUDIES IN A NORDIC CONTEXT
}

Halvor Moxnes

\begin{abstract}
This homage to Bruce Malina describes his visit to Norway in 1986, and reviews Nordic scholarship using social science criticism in New Testament and Early Christian studies in the last 40 years. Based on a common history and collaboration in academic politics, the Nordic countries make up a unity that has made it possible to establish Nordic studies in Early Christianity as a central player in international scholarship. Nordic scholars have especially been active in the second phase of social science criticism with its focus on social identities and ritual. Their most significant contribution has been in the exploration of socio-cognitive perspectives, where Helsinki University has had a leading role. A major discussion has been the relation between social-science criticism emphasizing the difference between antiquity and the modern world, and cognitive studies that focus on similarity. However, instead of absolute contrasts they may be regarded as supplementary approaches in historical studies of Early Christianity.
\end{abstract}

Key words: Nordic context, social-science criticism, socio-cognitive perspectives

It was at a Catholic Biblical Association meeting in the early 1980s that I met Bruce Malina for the first time.He had just published The New Testament World that should inspire many colleagues to try out social science perspectives in New Testament studies (Malina). I remember that I walked up to him and said: "I am the only Norwegian who has read your book!" This was a bold claim, and it resulted in many years of inspiration and challenges, as well as of friendship with him and Diana Jacobs Malina.

It also resulted in direct contact between Bruce Malina and other Contaxt Group members, and Nordic scholars. In the spring term of 1986 Bruce Malina was a Fulbrightprofessor at the Faculty of Theology at the University of Oslo. He lectured and advised 
several student papers on social anthropology and the New Testament, and participated in a research project on Early Christianity. As part of this project John H. Elliott and Jerome H. Neyrey came to Norway for a project seminar; and at a student seminar John Elliott presented lectures that became the beginnings of his important book, What is social-science criticism? (Elliott). Bruce Malina was also contacted by a PhD student in Trondheim, Torrey Seland, and introduced him to Mediterranean social anthropology and to a model of establishment violence that Seland used in his dissertation (Seland).

Bruce Malina's visit was not, however, the beginning of social science studies in New Testament scholarship in the Nordic countries; it was a study by the Swede Bengt Holmberg. But before we start on that history, it is in order to explain why the five Nordic countries (Denmark, Finland, Iceland, Norway and Sweden) are treated as a unity and introduced as "a Nordic context."

\section{What is the Nordic Context?}

These five countries in the Northern corner of Europe have many similarities: they are small in terms of population, they share a long history, apart from Finland their languages are closely related, they have a long democratic tradition, and the Lutheran church is the main confession in all countries. In terms of the institutional structure of academic studies, in all countries state universities is the rule, and due to the state church system, theological faculties were historically part of the university system; religious studies are more recent.

The context of Nordic New Testament and Early Christian studies is different from both Germany and North America. The Nordic system is more egalitarian and it does not have such dominant and wealthy institutions as Harvard and Yale. The Nordic countries have smaller academic and national systems so that the groups of teachers and $\mathrm{PhD}$ students in New Testament and Early Christianity at each institutions were usually quite small, and at times rather isolated.

This situation was radically changed due to initiatives from the Nordic Council, which represents all the Nordic countries, with an emphasis on collaboration in cultural politics and research. From the end of the 1990 there has a been a strong growth in Nordic collaboration in research and Ph.D. programs. A system of Nordic networks has over the years provided support for many different academic networks. Scholars in the area of religions in Antiquity have been especially active, with networks for instance on Early Christianity in a Greco- 
Roman context, on Nag Hammadi and on Qumran. This has resulted in more collaboration among colleagues at various universities, common courses for PhD students, and also Nordic participation in nationally funded projects. The result has been that in many areas in studies of religion in Antiquity groups of Nordic scholars work together. From an international perspective Nordic scholars appear as a group, often with one university in a leading position. For instance Helsinki has become a hub in studies in cognitive sciences, and Oslo has had a similar role in Nag Hammadi studies.

\section{Sociological beginnings}

In Europe the German scholar Gerd Theissen was a pioneer in sociological studies of the New Testament and Early Christianity, starting in the early 1970s. His approach was at first not recognized by the conservative establishment at the theological faculties at German universities, so he held his first professorship at Copenhagen University in a short period from 1978 till 1980. It was too short a period to get many followers, but one of his colleagues in Copenhagen translated his The First Followers of Jesus into Danish (Theissen 1979).

The first sociological analysis of New Testament texts by a Nordic scholar was Bengt Holmberg's Paul and Power, The Structure of authority in the primitive church as reflected in the Pauline epistles (Holmberg 1980). It started, as a dissertation at Lund University, Sweden, but was quickly published by an American press. For the purpose of this essay, the most interesting aspect of the study is Holmberg's description of his methodology. He lists a large number of theological studies of authority in Paul. Holmberg will present an alternative to the usual categories from theology, history of religion and later Christian theology. He has "chosen to interpret the data with categories taken from sociology, a field of scholarship seldom used by New Testament scholars" (Holmberg 1980, 5). When Holmberg sums up his methodological conclusions, he finds in theological studies of authority what he calls "the fallacy of idealism," they miss "an awareness of the continuous dialectic between ideas and social structures"(Holmberg 1980: 202). He argues that "the nature of authority is such that it is in itself a social phenomenon, not a theological interpretation of a social phenomenon"(Holmberg 1980: 204).

Holmberg's thesis from 1978 was a pioneer work, one of the first sociological studies of New Testament altogether, after Gerd Theissen, who figured prominently in the study together with Max Weber. The book was widely reviewed when it was published in 1980, and praised for its combination of historical and sociological approach. However, in his review 
Robin Scroggs raises a relevant criticism of the results of Holmberg's combination of historical and sociological analysis (Scroggs). He finds that Holmberg's substitution of "power" with "authority" results in a peaceful picture of the early church where conflicts always is overcome by the authority of the principal actors. Scroggs concludes that "Here the author of Acts has found a scholarly ally to help the presentation of an idealized early church gain credence," (Scroggs: 79). Scroggs' observations should make us question the claim that social-science methods and models provide "objective" answers; they may have implicit presuppositions that push the results in a specific direction. In Holmberg's case, his use of sociological methods went together with conservative positions with regard to church and theology.

A similar tendency appears to be present in his overview of sociological studies of the New Testament in Sociology and the New Testament, An Appraisal (Holmberg 1990).

Holmberg discusses studies from the period 1970 till 1990 under three different headings: the social level of the first Christians, early Christianity as a millenarian sect, and the correlations between symbolic and social structures. Denning Duling praises the book for "a masterful job of organizing an amazing variety of material," and a "handy analysis of methods and problems"(Duling: 82). However, Duling says, Holmberg cautions against cross-cultural studies and says that anthropology will be outside his scope, but nevertheless enters into criticism of such approaches. In conclusion, Holmberg warns that "we will not find the soul of early Christianity if we do not find the body "(Duling: 83). Duling finds that this warning may reflect the fear of a self-confessed conservative Lutheran theologian that sociological analysis may lead to losing the soul - also of contemporary Christianity. In recent years, Holmberg has not himself contributed much to sociological studies, but he has included sociological and social science perspectives in his projects and edited publications.

\section{Early influences from the Context Group}

When I was a visiting student at Yale in the early 1970s, Wayne A. Meeks started his studies on Paul that would result in his important and very influential study, The First Urban Christians (Meeks). I recall how we who were PhD students in Pauline studies were taken by surprise at this new approach, not focusing on Paul's theology, but asking "what was it like to be an ordinary Christian in the Pauline communities?" In order to find an answer, Meeks combined studies of the social context, social organization, rituals and expressions of beliefs, 
and he applied insights from sociologists like Weber and Durkheim and social anthropologists like Mary Douglas.

This somewhat eclectic approach met with criticism from scholars who about the same time formed the Context Group, who worked more explicitly with specific models from various social sciences. I learned much from colleagues and friends I had met at Yale and later at the Catholic Biblical Association: Jerome H. Neyrey, Bruce J. Malina and John H. Elliott. My first efforts at social anthropological studies of the New Testament were based on models of honor and shame and patronage (Moxnes 1988a, 1991). I also published introductions to the use of social anthropology and sociology in New Testament studies to Norwegian and Nordic audiences (Moxnes 1988c).

My first major work was a literary study of economic structures in Luke's Gospel, The Economy of the Kingdom, (Moxnes 1988b). Economy was an issue that was important at the time; Douglas Oakman had recently published Jesus and the Economic Question of his day (Oakman). In The Economy of the Kingdom I made use of a system of ancient economy constructed on the basis of historical and anthropological studies. That made it possible to understand the economy and social relations of Luke's society as a system of reciprocities (generalized, balanced and negative). I used this system to read the parables and the narrative sections of the gospels to give a picture of village life in Luke's society. The title The Economy of the Kingdom indicated that Jesus' parables and sayings set up a different economic system than that the villagers at Luke's time suffered under. I think this book showed a typical approach in these early studies: to focus on a question or a specific text, to outline a theoretical approach, and to use it to interpret the text or to draw historical inferences from the text.

\section{A Nordic Context and the Second Phase of Social Science Criticism}

It took time before social science criticism took hold in the Nordic countries, and when it happened, it was primarily in its second phase, moving beyond its beginnings with theories from social anthropology and ancient social, economic and political structures (e.g. T.F. Carney, James C. Scott ). The second phase broadened out to other theoretical perspectives and approaches, and with an awareness that the goal was not "objective" truth, but a conscious use of methods that would bring forth specific views. A part of this awareness was an engagement with the role of the interpreters, and how they shared presuppositions across disciplines: 
The developments in the second phase of social science criticism in Early Christian studies is outlined in the handbook Understanding the Social World of the New Testament edited by Dietmar Neufeld and Richard E. DeMaris (2010). The new approaches become visible especially in the section "Identity", for instance with essays on collectivism, kinship and family, constructions of gender in the Roman world, memory theory, ethnicity, landscape and spatiality (Neufeld and DeMaris: 15-106). Together with a focus on ritual, these approaches to a large extent cover the activities of Nordic scholars, especially many Finnish scholars. However, some Nordic scholars continued to work with issues taken from social anthropology. Especially Thomas Kazen has contributed many studies of the question of purity and impurity in Judaism and the historical Jesus (Kazen 2010a, 2010b).

\section{Social identities}

The term "identity" has become a new, very popular word, which seems almost to have replaced "theology" in discussions of the purpose of New Testament writings.(Moxnes 2005). This of course represents a conscious approach from scholars and it reflects a modern awareness, and therefore also makes use of modern theoretical perspectives. A group of Nordic scholars have been influenced by Philip Esler and his use of the social psychology of H. Tajfel and his Social Identity Theory; both in Helsinki (Jokiranta, Luomanen 2007) and in Sweden (Roitto). These studies of social identity show their link to a background in theological studies; they focus primarily on the constructions of Christian or Jewish identities in religious and social categories. The other major discussion of identity in Early Christianity is couched in the post-World War II category of "ethnicity", which replaced the discredited term "race". Ethnicity has now become the dominant term in discussions of Jesus and his background in Galilee. Although ethnicity is supposed to be a broad category, in many studies it functions in the narrow sense of "religion" (Moxnes $2010 \mathrm{c}$ ). Thus, with their focus on ethnicity, other aspects of identity as class, gender and place are often not brought into the picture.

\section{Gendered identities}

Gender issues have become very important in discussions of identity in studies inspired by sociology and social anthropology, and they may be categorized more under cultural studies than social scientific studies. Starting with studies of honor and shame in Early Christian texts, in the 1990s I continued with studies of families (Moxnes 1997) and attempted to integrate the perspectives of body, gender and space in the study of identity 
(Moxnes 2008). Feminist studies had made successful efforts to establish "woman" as an independent identity, not subsumed under "man". The emerging studies of masculinity attempted to do the same for "man". Feminist criticism had left "man" as an unexamined category, and masculinity studies started to explore how "man" (like "woman") was a constructed category. I made several investigations of how masculinity was constructed in various New Testament writings (Moxnes 2007), culminating with a study of the masculinity of Jesus as queer (not homosexual) in a historical construction in Putting Jesus in his Place. (Moxnes 2003).

Marianne Bjelland Kartzow, also at the University of Oslo, has contributed to gossip studies, with a specific purpose. She used the accusation of gossiping directed at women in 1 Timothy to explore the stereotyping of women by male authors of early Christian texts (Kartzow 2009). Later Kartzow was one of the first to develop feminist studies into intersectional approaches to Early Christianity (2012). Intersectionality has become an important analytical tool that feminist and anti-racist scholars use for theorizing identity and oppression. This approach highlights how mechanisms related to several categories can be understood as working together to construct human relations and classifications. One illuminating example is Kartzow's study of the categories of race, class and gender in Galatians 3:28 (Kartzow 2010). Instead of studying the different binary pairs in the passage in isolation (Jew or Greek, slave or free, male and female), intersectionality explores how these categoriemutually construct one another, and also construct hierarchies. An intersectional approach to this text reveals a web of social categories and gives a glimpse into the cultural and social complexity of antiquity. Thus, feminist and intersectional studies provide an invaluable approach to studies of social identities.

\section{Place and spatiality}

The term "social identity" illustrates how sociological studies have focused almost exclusively on social structures and relations in their investigation of identities. The importance of place and space for human identities has only very recently come into view, with new approaches in geography, philosophy and cultural studies. This has resulted in a new perspective on place, not just as a passive background for human interaction, but as a force interacting with social structures. A focus on place may also reflect a postmodern approach to studies of identity, not singularly focused on time, but also including place in the construction of identities. This has been a major interest for me in a number of studies from 
the end of the 1990s. I have focused especially on the importance of place for the construction of the historical Jesus in the context of house and household (Moxnes 2000), and of the historical Galilee (Moxnes 2001). These perspectives were brought together in Putting Jesus in His Place (Moxnes 2003). In Jesus and the rise of Nationalism (Moxnes 2012) I developed the perspective of Galilee as a place for Jesus into a study of how $19^{\text {th }}$ century scholars presented Galilee as a model for national identities in their own times.

\section{Socio-Cognitive Perspectives on Early Judaism and Early Christianity}

The most important contributions to new theoretical approaches coming from Nordic scholars engaged in social science criticism over the last 10 years have been in the area of socio-cognitive perspectives. With their many individual and joint publications Nordic scholars have had a leading role internationally in this area. Again Helsinki based scholars; especially Risto Uro, Petri Luomanen, Istvan Czachesz, Raimo Hakola and Jutta Jokiranta have been in the forefront, also in their capacity to establish research projects, to initiate joint publications and research collaboration. Participants from many Nordic networks (see above) joined together in a network on Socio-Cognitive Perspectives on Early Judaism and Early Christianity (2010-2013) chaired by Petri Luomanen. Helsinki University has been the focal point of this research and has the largest group of scholars in this area. The results from this network and its many seminars and scholarly collaborations are now in the process of being published (Byrskog, Hakola, Jokiranta; Roitto, Shantz, Luomanen).

Cognitive studies are now the most active field in what is generally labelled as social science criticism. But what is the relation between social sciences and cognitive sciences in New Testament studies? One of the first to write a $\mathrm{PhD}$ study using a cognitive perspective on a biblical text, Ephesians (Roitto), Rikard Roitto, presents it as a contrast to that which uses social sciences, especially anthropology: From the perspective of social anthropology religion was viewed as a socio-cultural system, and interpretation was undertaken in search of meaning. A major issue in interpretation was the cultural distance between the ancient biblical world and the modern interpreter, most often from the Western world. This is the main paradigm in Bruce Malina's The New Testament World, Insights from Cultural Anthropology ( Malina): the biblical world was characterized by collectivism, whereas the modern (US) world was based on individualism. Malina therefore emphasized difference rather than similarity between "us" and the subjects in ancient Mediterranean environment. In his study Roitto will emphasize that which is similar, since our minds in certain basic respects are not 
only analogous, but the same when it comes to the "biologically innate constraints and capacities of our minds" (Roitto 8).

In a major research article, Risto Uro develops this insight and places the approach that cognitive science represents to the study of Early Christianity within the context of a major paradigm shift (Uro 2017). He suggests that cognitive science now may serve to overcome the deep-rooted conflict between the sciences and the humanities, often assigned to "the two cultures." Cognitive studies is based on studies of the human mind (biology, neuroscience, psychology) that explore recurrent patterns of the human mind, and that constitute the basis for social behavior and common cultural types across time differences. There are now trends, Uro says, that bridge the gap between the social and the cognitive sciences, for instance social and social-anthropological theories that have included the psychological Social Identity Theory (se above). Uro suggests that cognitive science actually may supplement and counterbalance the approach by social sciences and humanities to New Testament and Early Christian studies. When the latter use the paradigm of difference between the ancient world and our modern world, that may be balanced by cognitive sciences that study early Christian texts, beliefs and rituals as results of human behavior, that is recognizable across time spans.

The first major publication of collaboration in cognitive science studies, edited by a Finnish group as early as 2007, was Explaining Christian Origins and Early Judaism: Contributions from Cognitive and Social Science (Luomanen, Pyysiainen; Uro). In her review, Colleen Shantz, who herself uses cognitive sciences, was positive to this collection of essays that introduced biblical scholers to "a new and productive set of approaches"(Shantz) . However, she warns against some temptations that what she terms "hard sciences" are especially prone to, e.g. that a hypothesis is presented as a proof. A more critical reviewer, Hal Taussig, focused on these temptations, especially that the essays "appeal to naturalized categories of analysis and assume that "science" has established a universal analytical vocabulary"(Taussig). Since that first collection, cognitive studies have been extended to new areas (see below), and a new collection of essays, Mind, Morality, and Magic: Cognitive Science Approaches in Biblical Studies edited by István Czachesz and Risto Uro (2013) presents the status of this research. They have both written presentations of cognitive science studies of the New Testament and Early Christian studies that serve as introductions to the field. Czachesz's Cognitive science and the New Testament. A New Approach to Early 
Christian Research (Czachesz 2017) is the most comprehensive in its coverage. Uro s Ritual and Christian Beginnings: A Socio-Cognitive Analysis (Uro 2016) uses ritual as his main example of how Early Christianity was shaped.

\section{Cognitive studies and blending theory in literary studies of the Gospels and Nag Hammadi texts}

In the examples above cognitive studies appear to be primarily part of biology and neuro science. But they may also be understood as part of the humanities. Two Norwegian scholars, Hugo Lundhaug and Kirsten Marie Hartvigsen have employed what they term "cognitive poetics" in interpretation of ancient texts, the Gospel of Philip and other Nag Hammadi texts (Lundhaug) and the Gospel of Mark (Hartvigsen), respectively. Instead of the common method in interpreting such texts by means of intertextuality, i.e. a comparison of texts, they employ studies of what goes on in the mind, i.e. cognitive linguistics in the form of blending theory. Blending theory builds on the processes in the mind where two or more mental spaces create new "blended spaces" which emerge from the combination of these spaces. For instance, in a study of the meaning of the crucifixion in the Gospel of Philip (Lundhaug 2014 a). Lundhaug shows how different images of the Tree of Knowledge are blended to shape the meaning of the tree of the Cross. Lundhaug has also used cognitive studies of collective memory, memory encoding, storage and recall to illuminate the processes of memorizing and memory control in early Egyptian monasticism (Lundhaug 2014b). These studies are undertaken as part of a large project on monastic manuscript culture in Egypt, funded by the European Research Council, which Lundhaug chairs at the University of Oslo,

\section{Memory}

In the collection of essays, Mind, Morality, and Magic (Czachesz and Uro), a section on "Memory and the transmission of biblical traditions," offers an instructive example of how cognitive science on the mind works in contrast to historical studies of memory. Two essays on cognitive studies and theories of memory by Petri Luomanen (Luomanen 2013) and István Czachesz (Czachesz 2013) introduce the section. They set up the approaches of cognitive studies of the functions of the brain in transmissions of biblical traditions as superior to the literary approaches of form criticism. Luomanen takes as his starting point an earlier protest against form criticism in terms of theories of memory and transmission of traditions about 
Jesus by the Swedish professor Birger Gerhardson in 1961 (Gerhardsson), updated by Richard Bauckham (Bauckham). Gerhardson and Bauckham argued that the disciples of Jesus used techniques of memory developed by rabbinical scholars, and that these techniques provided a trustworthy and controlled transmission of the words of Jesus. However, other studies show that forms of social control are more likely to remodel stories over the course of time. Luomanen argues that rather than focusing on models for memory, one should study memorizing as a process. Among the various theories on memory, Luomanen focuses on the so-called "flashbulb memories", that is, memories in the context of "sudden catastrophic or otherwise emotionally jarring events", that tend to create more reliable memories than those of ordinary events (Luomanen 2013: 38-39).

In a more technical study István Czachesz takes us into the function for memory by different parts of the brain. Knowledge of how much information the working memory can contain, how the storing of information is organized in the brain, and how it creates scripts, i.e. chains of elementary actions, is helpful for instance to interpret long lists of apostles, of Jesus' ancestors, and typical episodes like calling or healing stories. This approach, Czachesz argues, will critically reevaluate the models of the formation of New Testament texts used by form-criticism.

\section{Ritual Studies}

Ritual studies have become an important aspect of cognitive analysis of Early Christianity in the Nordic countries. The project Ritual and the Emergence of Early Christian Religion: A Socio-Cognitive Analysis (2013-2017), once more with its center in Helsinki, is chaired by Risto Uro. The most important result of this project so far is the monograph study by Uro, Ritual and Christian Beginnings: A Socio-Cognitive Analysis (Uro 2016). In this study Uro wants to show what cognitive science may contribute to historical studies of Early Christianity beyond what traditional historical studies may do. In order to do that, he interweaves three disciplines: ritual studies, cognitive science of religion (CSR) and the study of the New Testament and Early Christianity.

I can only take one example from the book, the baptism by John and how that contributed to a rise of a religious movement (Uro 2016: 71-98). Studies of John's baptism have mostly focused on the function of his immersion ritual in the cultural context of First century Judaism. But these studies have not observed the difference between his baptism and the common practice of immersion that was performed by people themselves. Uro therefore 
introduces a cognitive theory of ritual developed. by T. Lawson and R. Macauley. Their hypothesis is that people regard those rituals that are performed by an agent who is associated with a superhuman agent (e.g. God) as more powerful than those where the superhuman agent is associated with the "patient" of the ritual (the one upon whom the ritual is performed). The innovation that John the Baptist represented was that he "turned the Jewish self-administered water ritual into a special agent ritual" (Uro 2017, 528), that is, with him possessing the authority of a special agent. The ritual thus played a key role in motivating and mobilizing followers of John the Baptist. This effect could also be transferred to Jesus and to the movement of his followers. Thus, new questions and perspectives from cognitive science make ritual a crucial factor in the success of the Jesus movement, and this aspect would not otherwise have been recognized.

\section{Evaluation of Nordic approaches to "social-science" studies of Early Christian texts}

First of all, there is reason to recognize the contributions that Nordic scholars have made to studies of Early Christianity, especially over the period of the last 15 years. The output of publications, both individually and especially as result of collective cooperation, is impressive. More important, there is a willingness - and a competence - to explore new theories, methods and approaches that characterize these studies.

As I have already pointed out, behind these results lies a combination of intellectual strengths of individuals, a capacity among many scholars to show leadership, together with a high degree of collegiality and collaboration. This has happened within an institutional context that has been conducive to these results: a relatively egalitarian structure at academic institutions that makes it possible for many to show academic leadership and a willingness of institutions to support projects economically. Especially important has been the success in getting grants from national funding sources, as well as the important "seed money" from the Nordic Council for Nordic networks; in some cases also funding from the European Union. In the last ten years there is no doubt that the University of Helsinki, the institutions with the largest number of scholars and PhDs in New Testament and Early Christian studies, has provided leadership in terms of collaborative projects, in initiating and leading Nordic networks and projects, as well as programs within the Society of Biblical Literature.

It should also be noted that there have been good collaborations between scholars from theological institutions and from departments of religious studies. Many of the faculties of 
theology at Nordic universities are moving in the direction of integrating religious studies, and there is a general openness to theories and approaches not previously associated with theological studies. That held true for theories from sociology and social anthropology, and is now true for cultural studies and cognitive science.

However, there are also questions that can be raised to these new approaches, maybe in particular to the successful explorations into cognitive science approaches to biblical studies. It is obvious that it is more demanding to enter into new fields that lie farther afield from literary and historical biblical studies than do sociology and social anthropology. The need to explain how neuro science works before one can use the methodology in the study of texts and Early Christian history makes it a demanding work both for authors and readers (Czachesz 2016: 8-87).

The question of how these studies relate to other, contemporary approaches is also a matter of discussion. There is for instance little interaction with the perspectives of feminist studies or with the thematic issues of women in Early Christianity. Is there a danger that these approaches may neglect the advances that feminist (and masculinity) studies have made in making visible the gendered character of early Christian groups in their Mediterranean context (Taussig)?

Another question concerns the differences between what was initially termed social science criticism and the cognitive science approach when it comes to their position with regard to history. Social science criticism of the New Testament was an approach that explicitly would help explore early Christian texts in their difference from the modern context of the interpreters (see above). These differences were not only thought of as relevant for structures or organizations of societies, but also of psychology and mentalities (e.g. individualism versus collectivism). The general presupposition behind the cognitive sciences appears to be the opposite, of the similarity of the mind not only over generations, but over many thousands of years. Is there here a major difference in presuppositions that should have repercussions for the way we think of possibilities of changes, transitions and developments not only of social structures, but also of mentalities and perceptions?

In a recent essay Risto Uro enters into a discussion of these issues (Uro 2017: 518-25). He recognizes that social-scientific models for the study of Early Christianity are based on difference between the ancient Mediterranean world, based on collectivist values, and the modern world of individualism. Instead of seeing the cognitive science approach as an 
absolute opposite model, he suggests that it can be used to supplement that model, since there are "undeniable similarities between us and the people in the New Testament world" (Uro 2017: 524). Uro suggests that cognitive approaches can offer "tools for analyzing early Christian texts, beliefs, rituals etc. as results of human behavior." Uro therefore claims that the use of cognitive science does not mean to give up the task of an historian, but that cognitive science can provide theories and tools that can contribute to historical and cultural analyses. Coming from one of the main practitioners of cognitive studies, this seems a fitting conclusion to this discussion.

\section{Works cited}

Bauckham, Richard 2006. Jesus and the Eyewitnesses: The Gospels as Eyewitness Testimony. Grand Rapids, MI: Eerdmans.

Byrskog,Samuel, Raimo Hakola, Jutta Maria Jokiranta, Eds. 2016. Social Memory and Social Identity in the Study of Early Judaism and Early Christianity. Göttingen: Vandenhoeck \& Ruprecht.

Czachesz, István 2017. Cognitive science and the New Testament. A New Approach to Early Christian Research. Oxford: Oxford University Press.

2013. "Rethinking biblical transmission: insights from the cognitive neuroscience of memory.” Pp. 43-61 in Czachesz and Uro .

Czachesz, István and Risto Uro, eds. 2013. Mind, Morality, and Magic: Cognitive Science Approaches in Biblical Studies . Durham UK: Acumen.

Duling, Dennis 1992."Review of Bengt Holmberg, Sociology and the New Testament." in Interpretation 46: 82-83.

Elliott, John H. 1993. What is social-science criticism? Minneapolis: Fortress.

Gerhardsson, Birger 1961. Memory and Manuscript: Oral Tradition and Written

Transmission in Rabbinic Judaism and Early Christianity. Lund: Gleerup.

Hartvigsen, Kirsten Marie 2012. Prepare the way of the Lord: towards a cognitive poetic analysis of audience involvement with characters and events in the Markan world. BZNW 180. Berlin: de Gruyter. 
Holmberg, Bengt 1980. Paul and Power, The structure of authority in the primitive church as reflected in the Pauline epistles. Philadelphia: Fortress.

Jokiranta, Jutta 2013. Social Identity and Sectarianism in the Qumran Movement, STDJ 105. Leiden: Brill.

Kartzow, Marianne Bjelland 2012. Destabilizing the Margins: An Intersectional Approach to early Christian Memory Eugene, OR.: Wipf and Stock .

2010. "Asking the Other Question: An Intersectional Approach to Galatians 3:28 and the Colossian Household Codes." Biblical Interpretation 18: 364-389.

2009. Gossip and Gender: Othering of Speech in the Pastoral Epistles. BZNW 164 Berlin; New York:: DeGruyter, .

Kazen, Thomas 2010a. Issues of Impurity in Early Judaism. ConBNT 45. Winona Lake, In: Eisenbrauns.

2010b. Jesus and Purity Halakhah: Was Jesus Indifferent to Impurity? ConBNT 38. Corrected reprint edition. Winona Lake, In.: Eisenbrauns.

Lawson, E. Thomas and Robert N. MaCauley, 1990. Rethinking Religion: Connecting Cognition and Culture. Cambridge: Cambridge University Press.

Lundhaug, Hugo 2010. Images of Rebirth: Cognitive Poetics and Transformational Soteriology in the Gospel of Philip and the Exegesis on the Soul. Leiden: Brill.

2014a. "The Fruit of the Tree of Life: Ritual Interpretation of the Crucifixion in the Gospel of Philip.” Pp. 73-97 in Cognitive Linguistic Explorations in Biblical Studies, edited by Bonnie Howe \& Joel B. Green. Berlin: de Gruyter.

2014b. "Memory and Early Monastic Literary Practices: A Cognitive Perspective." Journal of Cognitive Historiography 1: 98-120.

Luomanen, Petri 2013. "How Religions Remember: Memory Theories In Biblical Studies and in the Study of Cognitive Study of Religion.” Pp. 24-42 in Czachesz and Uro.

2007. "The Sociology of Knowledge, the Social Identity Approach and the Cognitive Science of Religion.” Pp. 199-229 in Explaining Christian Origins and Early Judaism: Contributions 
from Cognitive and Social Science, edited by P. Luomanen, I. Pyysiäinen and R. Uro. BibInt Series 89. Leiden: Brill.

Luomanen, Petri, Ilkka Pyysiainen; Risto Uro, eds. 2007. Explaining Christian Origins and Early Judaism: Contributions from Cognitive and Social Science. Biblical interpretation Series 89; Leiden: Brill.

Malina, Bruce J. 1981. The New Testament World, Insights from Cultural Anthropology . Atlanta: John Knox Press.

Meeks, Wayne A. 1980. The First Urban Christians. The Social World of the Apostle Paul. New Haven, Conn: Yale University Press.

Moxnes, Halvor

2010. "Identity in Jesus' Galilee. From Ethnicity to Locative Intersectionality," Biblical Interpretation 18: 390-416.

2008. "Body, Gender and Social Space. Dilemmas in Constructing Early Christian Identities." Pp. 163-81 in Identity Formation in the New Testament, edited by Bengt Holmberg and Mikael Winninge. WUNT 227. Tübingen: Mohr Siebeck.

2007. "Where is 'Following Jesus'? Masculinity and Place in Luke's Gospel."Pp. 15570 in In Other Words. Essays on Social Science Methods and the New Testament in Honor of Jerome H. Neyrey, edited by Anselm C.Hagedorn et al. The Social World of Biblical Antiquity, Second Series 1. Sheffield: Sheffield Phoenix Press.

2005. "From Theology to Identity: The Problem of Constructing Early Christianity." Pp. 264-81 in Moving Beyond New Testament Theology?: Essays in Conversation with Heikki Räisänen, edited by T. Penner and C. Vander Stichele: Helsinki: Finnish Exegetical Society.

2003. Putting Jesus in his Place. A Radical Vision of Houeshold and Kingdom. Louisville KY: WestminsterJohnKnox.

2001. "The Construction of Galilee as a Place for the Historical Jesus."Biblical Theology Bulletin 31: 26-37, 64-77. 
2000. "Placing Jesus of Nazareth. Towards a Theory of Place in the Study of the Historical Jesus." Pp. 158-75 in Text and Artifact in the Religions of Mediterranean Antiquity. Essays in Honour of Peter Richardson, edited by Stephen G. Wilson and Michel Desjardins. Studies in Christianity and Judaism 9. Waterloo, On: Wilfrid Laurier University Press.

1997. Ed. Constructing Early Christian Families. Family as Social Reality and Metaphor. London: Routledge.

1991. "Patron-Client Relations and the New Community in Luke-Acts" pp. 241-68 in The Social World of Luke-Acts. Models for Interpretation, ed. by Jerome H. Neyrey. Peabody, MA: Hendrickson.

1988a. "Honour and Righteousness in Romans." Journal for the Study of the New Testament 32: 61-77.

1988b. The Economy of the Kingdom. Social Conflict and Economic Relations in Luke's Gospel. Philadelphia: Fortress.

1988c. "Sociology and the New Testament." Pp. 143-59 in Religion as a social phenomenon. Theologians and Sociologists Sharing Research Interests, edited by Erik Karlsaune. Trondheim: Tapir.

Neufeld, Dietmar and Richard E. DeMaris eds. 2010: Understanding the Social World of the New Testament. London: Routledge.

Oakman, Douglas E. 1986. Jesus and the economic questions of his day. Lewiston, NY: Mellen.

Roitto, Rikard 2011. Behaving as a Christ-Believer: A Cognitive Perspective on Identity and Behavior Norms in Ephesians. Winona Lake, IN: Eisenbrauns.

Roitto, Rikard, Colleen Shantz, and Petri Luomanen, eds. Forthcoming, Social and Cognitive Perspectives on the Sermon on the Mount. London: Equinox.

Scroggs, Robin 1983. "Review of Bengt Holmberg, Paul and Power." Journal of Religion 63, 78-79.

Seland, Torrey. 1995. Establishment violence in Philo and Luke: a study of non-conformity to the Torah and Jewish vigilante reactions. Biblical interpretation series 15. Leiden: Brill. 
Shantz, Colleen 2009. "Review of Luomanen etc., Explaining Christian Origins. “ Biblical Theology Bulletin 39: 166-67:

Taussig, Hal 2010. "Review of Luomanen etc., Explaining Christian Origins.” Biblical Interpretation 18: 188-90.

Theissen, Gerd 1979. Jesus-overleveringen og dens sociale baggrund. Et sociologisk bidrag til den tidligste kristendoms historie. Transl. Geert Hallbäck. København: Hans Reitzel.

Uro, Risto 2017. "Cognitive Science in the Study of Early Christianity: Why is it Helpful and How?" New Testament Studies 63: 516-33.

2016. Ritual and Christian Beginnings: A Socio-Cognitive Analysis. Oxford: Oxford University Press. 